\title{
KETIDAKADILAN GENDER PADA ACARA TV SINEMA INDOSIAR: TELAAH PERSPEKTIF STRUKTURASI GIDDENS
}

\author{
Fitrinanda An Nur ${ }^{1}$, Ade Audyana ${ }^{2}$, Rahayu Gurniawati ${ }^{3}$ \\ Prodi Ilmu Komunikasi, Universitas Ahmad Dahlan \\ Email: fitrinanda@comm.uad.ac.id
}

\begin{abstract}
Abstrak
Tulisan ini menelaah permasalahan ketidakadilan gender dalam perspektif strukturasi Giddens. Melihat kasus ketidakadilan ini telah mengakar pada kehidupan, terutama pada pembagian kerja perempuan yang cenderung menempatkan kembali perempuan pada ranah domestik. Persoalan ini tentu tidak terlepas dari pengaruh media selaku agen yang memiliki kuasa terhadap pembentukan pemikiran khalayak, dan juga peran masyarakat yang memiliki kuasa dalam membentuk struktur sosial. Media memliki power dalam memproduksi dan mereproduksi sebuah wacana. Penelitian ini merupakan penelitian dengan metode kualitatif deskriptif dan menggunakan teori Strukturasi Giddens dalam melihat peran agen dalam menggambarkan perempuan dalam media. Penelitian ini berfokus pada acara sinema Indosiar. Hasil dari penelitian menunjukan perempuan masih menjadi objek dari penindasan dan perempuan akan kembali pada ranah domestik, bahkan perempuan justru menanggung beban ganda (double burdon) apabila ia bekerja pada ranah publik, ia juga tetap berkerja di wilayah domestik. Media melanggengkan hal tersebut melalui kisah-kisah yang ditampilkan.
\end{abstract}

Kata Kunci: strukturasi; perempuan; ketidakadilan;gender

\begin{abstract}
This paper examines the issue of gender injustice in the perspective of Giddens structuration. Cases of this injustice rooted in life, especially in the women's division of labor that would likely put back women in the domestic sphere. This issue is certainly inseparable from the influence of the media as an agent who has the power to shape the thinking of the public, and also the role of the people who have the power in shaping social structures. The media has the power to produce and reproduce a discourse. This research is a descriptive qualitative research method and uses Giddens structuration theory in looking at the role of agents in portraying women in the media. This research focuses on the Indosiar cinema program. This research focuses on the Indosiar cinema program. Results from the study showed women still be the object of oppression and women will return to the domestic sphere, the study also showed that women face with a double burden. If she works in the public sphere, she also continues to work in the domestic sphere. The media perpetuates this through the stories that are displayed.
\end{abstract}

Keyword:; structuration; women; injustice; gender 


\section{PENDAHULUAN}

Tulisan ini bertujuan untuk melihat permasalahan gender dalam perpsektif strukturasi. Permasalan gender berkutat pada bentuk ketidakadilan gender yang terdapat dalam kehidupan sehari-hari, termasuk dalam perihal pembagian kerja, yang pada akhirnya memposisikan perempuan kembali pada wilayah dosmetik. Media tentunya berperan penting dalam melanggengkan hal ini. Karena media memiliki power dalam membentuk pikiran khalayak. Dalam perspektif strukturasi, Giddens mempercayai bahwa agen tidak berarti tanpa kekuasaan. Manusia sebagai pemain dan juga agen disini memiliki kuasa untuk menaruh pemaknaan terhadap ketidakadilan gender ini.

Sebelum jauh membahas gender dalam perspektif strukturasi, lebih dulu memahami perbedaan gender dan jenis kelamin. Perbedaan antara laki-laki dan perempuan dapat dijelaskan oleh Tong (1998) bahwa gender adalah terpisah dari jenis kelamin, masyarakat patriarkal menggunakan peran gender yang kaku. Untuk memastikan bahwa perempuan tetap pasif (penuh kasih sayang, penurut, tanggap terhadap simpati dan persetujuan, ceria, baik, dan ramah) dan laki-laki tetap aktif (kuat, agresif, penuh rasa ingin tahu, ambisius, penuh rencana, bertanggung jawab, orisinil, dan kompetitif). Karena itu, cara bagi perempuan untuk menghancurkan kekuasaan laki-laki yang tidak layak atas perempuan, adalah dengan menyadari bahwa perempuan tidak ditakdirkan untuk menjadi pasif, dan juga laki-laki tidak ditakdirkan untuk menjadi untuk menjadi aktif.

Sejak Sekolah Dasar kita juga telah disugesti mengenai pembagian kerja menurut gender, dimana ibu memasak di dapur dan bapak bekerja di kantor. Pembagian kerja ini yang terkonstruk sebagai pembagian gender yang kita yakini. Perempuan akan bekerja didapur dan laki-laki akan bekerja di kantor. Ketika menyalahi aturan maka hal tersebut dianggap tidak normal dan menyalahi kodratnya. Padahal arti dari kata kodrat itu sendiri merupakan suatu ketentuan yang tersemat dan tidak bisa dikendalikan, diubah ataupun ditukarkan kepemilikannya oleh manusia ke manusia yang lainnya. Salah satunya yakni kepemilikan seks (jenis kelamin) dan akibat dari kepemilikan seks tersebut. Contohnya, kodrat yang ada pada setiap perempuan yaitu mengandung dan melahirkan. Tentu hal tersebut tidak bisa disamakan dengan pembagian peran sosial yang kini melekat sebagai konstruk pada laki-laki dan perempuan. Pada dasarnya sepanjang yang kita ketahui, sebenarnya peran dan fungsi gender tersebut dapat dipertukarkan antara laki-laki dan perempuan tanpa menyalahi kodratnya. Dengan kata lain konsep gender merupakan hasil dari adanya perbedaan fungsi sosial pada suatu lingkungan.

Perbedaan konsep gender secara sosial melahirkan perbedaan peran, fungsi, bahkan ruang dimana laki-laki dan perempuan beraktivitas dalam masyarakat. Perbedaan gender yang melekat pada cara pandang masyarakat membuat kita lupa bahwa hal itu bukanlah kodrat atau sesuatu yang permanen. Sebagaimana permanennya ciri-ciri biologis yang dimiliki oleh perempuan dan laki-laki.

Menurut Fakih (1996), gender merupakan sifat yang melekat pada kaum laki-laki dan perempuan yang dikonstruksi secara sosial maupun kultural. Jenis kelamin berkaitan dengan 
pemberian sifat,pembagian dua jenis kelamin manusia ini ditentukan secara biologis yang melekat pada jenis kelamin tertentu. Misalnya, laki-laki memiliki alat kelamin yang disebut penis. sementara perempuan memiliki jenis kelamin yang disebut vagina. Hal ini yang dikatakan dengan kodrat, sebab ini merupakan pemberian Tuhan secara biologis dan tidak dapat diganggu gugat, tidak dapat dipertukarkan.

Industri pertelevisian di Indonesia sebagai salah satu komoditas terbesar, dimana berbagai televisi swasta saling berkompetisi merebut minat pemirsa melalui tayangannya. Budaya menonton dianggap sebagai hobi masyarakat, tidak heran jika televisi masih menjadi media massa yang paling banyak diminati. Hampir setiap rumah diseluruh penjuru Indonesia mempunyai televisi, bahkan terkadang tidak cukup hanya mempunyai satu televisi saja. Keberagaman tayangan yang ditawarkan televisi menjadikannya sebagai media elektronik di masyarakat. Dalam televisi terdapat beberapa genre tayangan yaitu news, drama, variety, sport, advertising dan lain sebagainya. Banyaknya genre yang ditawarkan membuat masyarakat bebas memilih tayangan apa yang ingin mereka tonton. Namun, dari banyaknya gender sinetron atau drama masih saja menjadi tayangan yang digemari mayoritas masyarakat. Tidak mengherankan karena sinetron seringkali diambil dari refleksi kehidupan di masyarakat.

Dalam ini media khususnya TV juga ikut andil dalam mengkonstruksi dan melanggengkan bentuk ketidakadilan gender ini. Media sebagai salah satu tempat informasi, serta merta memberikan kita pandangan terhadap diskriminasi gender. Penempatan laki-laki dan perempuan yang tidak seharusnya, semakin membuat perempuan tetap berkutat dalam ranah domestik. Sebagaimana yang disinggung oleh Hollows (2010), peran media dalam menampilkan posisi seorang perempuan secara tidak langsung memberikan pengetahuan kepada penontonnya mengenai 'peran jenis kelamin tradisional' selain itu juga mengajarkan agar mereka harus 'mengarahkan hati mereka pada dapur dan rumah tangga.

Hal tersebut dapat dilihat acara Sinema Indosiar, acara ini merupakan sinema drama keluarga. Kisah suka duka perjalanan dan perjuangan kehidupan orang-orang yang dibumbui dengan intrik, konflik, dan cobaan berliku. Dibintangi oleh deretan aktor aktris Indonesia. Berdasarkan cerita yang ditayangkan pada Sinema Indosiar, secara tidak langsung menempatkan perempuan sebagai objek yang tertindas dan sengsara. Namun, sebaliknya apabila perempuan tersebut tidak tertindas, ia akan menjadi perempuan yang menindas perempuan lainnya. Sosok perempuan gila harta, dan perempuan yang lemah sangat kuat ditampilkan dalam TV di Indonesia. Salah satunya adalah Indosiar. Judul Sinema Indosiar "Waktu Miskin Sayang Keluarga, Ketika Kaya Lupa Dunia" atau pun "Suamiku Pelitnya Minta Ampun" dsb, yang menampilkan bagaimana sosok perempuan yang hanya berkutat pada wilayah domestik bahkan rela mengerjakan pekerjaan rumah hanya untuk suami.

Pada dasarnya, adanya hal tersebut juga di pengaruhi budaya patriarki di Indonesia yang menempatkan laki-laki sebagai pemegang saham terbesar dalam kepemimpinan politik, otoritas moral, hak sosial hingga penguasa properti. Menurut Alfian Rokhmansyah (Pengantar Gender dan Feminist : 2013) patriarki menempatkan peran laki-laki sebagai penguasa tunggal dan sentral dari segala-galanya. Sistem ini membawa sebuah dasar "hak istimewa" bagi kaum laki-laki dan menjadikan perempuan sebagai objek yang berguna jika dapat dieksploitasi. 
Patriarki juga menempatkan laki-laki sebagai kontrol utama di masyarakat, sehingga dominasi terhadap perempuan tidak dapat terelakan.

Dominasi ini dikarenakan, adanya struktur yang berkembang di masyarakat, bahwa yang berhak melakukan pekerjaan rumah adalah perempuan, laki-laki bekerja di luar. Sedari kecil, kita sudah menyepakati hal ini, pada saat pelajaran di sekolah, kita di ajari bahwa 'ibu memasak, ayah bekerja di kantor'. Sedangkan pada kehidupan sehari-hari, misalnya pembagian kerja kita juga dipengaruhi oleh budaya patriarki. Sehingga keluwesan dalam mengemukakan pendapat dan penempatan kerja sulit dilakukan oleh perempuan. Pada beberapa kasus terjadi jika perempuan ingin bekerja harus memenuhi syarat bahwa ia belum menikah, dan apabila sudah menikah ia hanya ditempatkan pada posisi yang tetap saja di bawah laki-laki.

Tulisan ini berupaya melihat gambaran ketidakadilan gender khususnya pada penempatan atau pembagian kerja bagi perempuan di media TV di Indonesia. Peneliti berfokus pada Sinema Indosiar, dengan menggunakan teori strukturasi Giddens. Dengan Tujuan memaparkan penggambaran pembagian kerja perempuan di acara sinetron Indonesia dan menjelaskan mengenai pandangan teori sturkturasi Giddens terkait penggambaran perempuan di acara sinetron Indonesia

\section{METODE PENELITIAN}

Penelitian ini menggunakan metode kualitatif dengan analisis menggunakan teori strukturasi Giddens. Objek penelitian ini adalah sinetron di TV Indonesia, pengumpulan data dengan menggunakan teknik primer dan sekunder. Primer didapatkan dari sinetron yang ada di TV, sekunder didapatkan dari studi pustaka, yaitu jurnal, buku, dan penelitian terdahulu.

\section{HASIL dan PEMBAHASAN}

\section{Ketidakadilan Gender}

Strukturasi atau proses menciptakan hubungan sosial, terutama mereka yang diselenggarakan di sekitar kelas sosial, jenis kelamin, dan ras. Misalnya, ekonomi politik menggambarkan bagaimana akses ke media massa dan teknologi komunikasi baru dipengaruhi oleh kesenjangan kelas sosial yang membagi orang menurut pendapatan dan kekayaan (Mosco, 2009). Strukturasi berangkat dari pemikiran Anthony Giddens, bahwa strukturasi menggambarkan mengenai perubahan sosial sebagai proses yang mendeskripsikan bagaimana struktur diproduksi dan direproduksi oleh manusia yang berperan sebagai pelaku dalam struktur itu sendiri.

Anthony Giddens adalah seorang ilmuan sosial kelas dunia yang menjadi dosen sosiologi di University of Cambridge. Sebagai seorang ilmuan Giddens tidak hanya menghasilkan karya tulis bermutu yang diukur secara kualitatif namun juga pemikir yang produktif secara kuantitatif. Giddens seorang teoritikus sosial yang membangun teorinya secara eklektik. Ia mengkritik teori sosial yang menjadi tradisi ortodoks dan menggunakan bagian-bagiannya sebagai titik tolak kritis untuk membangun teorinya sendiri. Teori 
strukturisasi dibangun ketika Giddens memusatkan perhatiannya pada upaya untuk merekontruksi secara radikal teori sosial karena teori yang tidak memadai lagi memahami kondisi masyarakat modern dan perubahan sosial didalamnya

Giddens menyatakan bahwa agency menyangkut kejadian yang dilakukan seorang individu, keagenan berarti peran individu, apapun yang terjadi, takkan menjadi struktur seandainya individu tidak mencampurinya (Giddens, 1984:9). Giddens memberikan kekuasaan besar terhadap agen, dengan kata lain, menurutnya agen mempunyai kemampuan untuk menciptkan pertentangan dalam kehidupan sosial, dan bahkan ia lebih yakin lagi bahwa agen tak berarti apa-apa tanpa kekuasaan. Giddens berpendapat bahwa struktur hanya ada di dalam dan melalui aktivitas agen manusia (Ritzer dan Goodman, 2010).

Struktur mempengaruhi agensi dalam dua arti yaitu memampukan (enabling) dan menghambat (costraining). Terjadinya paradoks dalam struktur ini karena Giddens memandang struktur sebagai hasil (outcome) sekaligus sarana (medium) praktik sosial. Bukan merupakan totalitas gejala, kode tersembunyi seperti strukturalisme, dan kerangka keterkaitan bagian-bagian dari suatu totalitas seperti yang dipahami fungsionalis. Dalam pandangan Giddens, agensi dapat meninggalkan struktur dan tidak selalu patuh pada struktur. Ia memiliki kesempatan untuk keluar dari peraturan dan ketentuan yang ada.

Giddens (1984) mengelompokkan struktur menjadi tiga gugus, yaitu struktur sebagai penanda atau signifikasi (signification) yang menyangkut pemaknaan, penyebutan dan wacana. Kedua, domination (dominasi) mengenai penguasaan atas orang (politik) dan barang (economy) dalam kaitannya ini Giddens mengambil contoh dari pemikiran Marx dalam modern capitalism. Ketiga, adalah legitimation (pembenaran) yang berkaitan dengan peraturan normatif.

Pada tatanan praktik sosial, ketiga gugus prinsip struktural Giddens saling berkaitan. Struktur signifikan pada praktiknya akan mencangkup kedua gugus prinsip berikutnyan yakni dominasi dan legitimasi. Pada kasus gender, signifikasi laki-laki pada dasarnya akan menyangkut prinsip dominasi, berupa otoritas laki-laki pada perempuan atau otoritas suami pada isteri. Sementara itu, prinsip legitimasi akan mengikuti ketika seorang suami berhak membatasi peran isterinya misalnya dalam lingkungan masyarakat.

Sunarto (2009) mengatakan bahwa strukturasi gender terkait dengan konsep struktural Giddens yaitu dengan menambahkan elemen gender pada struktur signifikasi, dominasi dan legitimasi. Dalam pemikiran semacam ini, terjadinya struktur dominasi gender hanya dimungkinkan ketika struktur signifikasi dan legitimasi memberikan justifikasi terhadap kekuasaan kaum pria atau kaum perempuan melalui mekanisme kursif dan persuasif tertentu.

Strukturasi adalah produksi dan reproduksi sistem sosial melalui :1) Konsep sistem sosial dengan memberikan definisi sietem sosial sebagai relasi gender asimetris yang dipengaruhi patriarkisme dan kapitalisme, 2) Konsep aktor dengan membedakannya menjadi agen pria dan agen perempuan, 3) Konsep interaksi dengan menunjukkan lokasi terjadinya interaksi di ranah domestik dan ranah publik melalui tindakan-tindakan represif, 4) Konsep aturan melalui pengetahuan tentang sistem tanda dan norma-norma seksualitas, 5) Konsep 
sumber daya melalui kekuasaan terkait dengan kepemilikan fasilitas alokatif dan otoritatif yang mensubordinatkan, mengalienasikan dan mendiskriminasikan kaum perempuan dari kepemilikan sumber daya di ranah publik.

Dalam perkembangannya peran perempuan dan laki-laki sangat mencolok dalam hal pembagian kerja. Perempuan diberi tanggungjawab untuk meramu biji-bijian, membudidayakan tanaman pangan, memasak, dan membuat perabotan rumah tangga. Ketika kaum laki-laki berkonsentrasi untuk perburuan binatang dan peperangan (Evans, 1994). Pada akhirnya, pola-pola yang ini membentuk kesenjangan dan kelas-kelas sosial. Terkait dengan strukturasi yang mempermasalahkan struktur sosial di masyarakat.

Permasalahan gender yang terjadi bukan mengenai pekerjaan perempuan seperti mengasuh atau merawat. Mansour Fakih (1996) memberikan penjelasan mengenai gender differences (perbedaan gender) yang melahirkan peran gender (gender role) dan dianggap tidak menimbulkan masalah. Jadi, secara biologis (kodrat perempuan dengan organ reproduksinya akan hamil, melahirkan, menyusui dan kemudian mempunyai peran gender sebagai perawat, pengasuh dan pendidik anak, sesungguhnya tidak ada masalah. Namun, akan menjadi masalah ketika adanya struktur 'ketidakadilan' yang ditimbulkan peran dan perbedaan gender. Akhirnya muncul berbagai manifes ketidakadilan seperti, marginalisasi, subordinasi, pelabelan negatif, kekerasan, dan perempuan menanggung beban kerja domestik yang lebih banyak.

Sementara itu, marginalisasi merupakan bentuk ketidakadilan gender yang melahirkan permasalahan ekonomi. Dalam pekerjaan, perempuan justru ditempatkan dalam posisi gender kedua, misalnya perempuan ketika diposisikan menjadi sekretaris dengan gaji yang lebih rendah daripada laki-laki. Subordinasi dinilai sangat merugikan kaum perempuan, anggapan bahwa perempuan adalah sosok yang emosional membuat perempuan tidak dipercaya untuk ikut serta ke ranah publik. Pelabelan negatif atau stereotipe juga menambah daftar panjang mengenai kasus ketidakadilan gender, pandangan bahwa perempuan yang keluar malam adalah perempuan yang tidak baik, pandangan perempuan bersolek merupakan cara perempuan menarik perhatian laki-laki dan menomorduakan pendidikan perempuan, karena anggapan bahwa tugas perempuan adalah melayani suami, hal tersebut merupakan proses pelabelan terhadap perempuan (Fakih, 1996).

Celakanya, pembentukan kata kodrat pada perempuan justru dimaknai berbeda oleh masyarakat. Kodrat berarti sesuatu yang telah diberikan oleh Tuhan, dan hal ini tidak dapat dibantah lagi. Kegiatan perempuan seperti mendidik anak, mengerjakan pekerjaan rumah adalah kodrat perempuan. Kodrat juga seringkali disamakan dengan beban gender. Padahal kodrat seharusnya lebih relevan jika disamakan dengan atribut gender. Pola pemberian beban gender dalam lintas budaya mengacu pada perbedaan atribut gender dan jenis kelamin. Perbedaan yang telah diciptakan di lingkungan masyarakat yang telah menjadi budaya akan mengakibatkan perbedaan perlakuan yang diterima masing-masing gender. Padahal, kegiatan ini adalah pembentukkan budaya, bisa jadi semua kegiatan tersebut daapat dilakukan oleh lakilaki. Kesalahan dalam memaknai kodrat justru membuat perempuan terkukung dalam wilayah domestiknya. Dalam kacamata sistem dan aktor, sebuah sistem akan mempengaruhi tindakan 
aktor. Sistem yang dibentuk dan dipertukarkan akan menghasilkan serangkaian tindakan aktor. Oleh karenanya, apabila sebuah sistem dijalankan dalam lingkup yang salah, maka aktor pun akan melakukan yang serupa. Sistem diibaratkan sebagai media dan aktor adalah masyarakat. Masyarakat akan melihat bagaimana media menampilkan laki-laki dan perempuan dan kemudian hal ini diterima masyarakat, hasil akhir adalah pada masyarakat yang memberikan penilaian serta opininya.

\section{Peran Media dalam Merepesentasikan Perempuan}

Media selaku pusat informasi telah banyak membentuk pikiran masyarakat, baik itu dalam film, majalah, koran, ataupun televisi. Dalam kaitannya dengan permasalahan gender, media tentunya memiliki kekuatan dalam mengkonstruksi pikiran masyarakat dengan cara merepresentasikan sebuah permasalahan dengan kepentingannya sendiri. Realitas sosial dipindahkan oleh media ke dalam pesan media atau setelah diubah sitranya melalui replika citra ke dalam realitas sosial baru di masyarakat. Kekuatan media juga mampu mengatur jadwal kegiatan kehidupan bermasyarakat.

Televisi adalah medium fiktif yang sangat berpengaruh dalam masyarakat kontemporer. Televisi lahir dari kombinasi teknologi, industri, event ideologis dan politis masyarakat. Program dari berbagai stasiun televisi menjadikan televisi sebagai media yang memberi peluang besar kepada audience dengan sifatnya yang audio-visual, sehingga pesan atau informasi yang disampaikan sangat mudah menarik serta diterima oleh masyarakat. Televisi juga sebagai media yang memiliki kekuatan membentuk opini publik bahkan citra dimasyarakat. Bisa dikatakan semua orang senang menonton televisi padahal sebenarnya televisi penuh dengan permainan ideologis. Pemelihara dan pembentuk kontruksi sosial dengan beragam pandangan, misalnya cara pandang terhadap laki-laki dan cara pandang terhadap perempuan. Bagaimana cara televisi memandang perempuan dalam sebuah perpektif budaya, yang pada akhirnya memperteguh kondisi perempuan yang tersubordinasi dalam dunia televisi.

"Dalam Newsletternya Nielsen menyebutkan 11 persen dari total penonton TV adalah remaja berusia 15-19 tahun, dan kebanyakan di antara mereka adalah perempuan. Pada target pemirsa ini, potensi penonton remaja perempuan lebih tinggi daripada laki-laki di semua paruh waktu, dimana populasi perempuan mencapai 2,3 juta, sedikit lebih banyak daripada populasi laki-laki yang 2,2 juta di 10 kota survei AGB Nielsen. Karena potensi pemirsa terbesar berada di jam tayang utama, umumnya program dengan rating tertinggi di kalangan remaja juga yang ditayangkan pada paruh waktu ini. Diantara remaja pun, jenis kelamin berperan dalam pemilihan program, remaja perempuan banyak menonton musik dan drama, remaja laki-laki memilih untuk menyaksikan olahraga, sepakbola atau bulutangkis, baik asing maupun lokal. Rata-rata remaja perempuan menghabiskan 2 jam 56 menit sehari untuk menonton TV, sedangkan remaja laki-laki meluangkan waktu yang lebih sedikit, 2 jam 17 menit." (Endri Listiani : 2015). 
Representasi merujuk pada bagaimana seseorang kelompok atau pendapat tertentu ditampilkan dalam sebuah pemberitaan atau wacana. Merepresentasikan akan bersifat subjektif, sebab penggambaran yang ditampilkan bisa baik atau justru sebaliknya. "Representasi bukan penjiplakan atas kenyataan yang sesungguhnya, representasi adalah ekspresi estetis, rekonstruksi dari situasi sesungguhnya" (Barker, 2005:104). Bagi Barker representasi sendiri dimaknai sebagai bagaimana dunia dikonstruksikan secara sosial dan disajikan kepada kita dalam pemaknaan tertentu. Dalam hal ini sebenarnya media mengungkapkan suatu peristiwa yang pada dasarnya adalah mengkonstruksi sebuah realitas, bisa dikatakan bahwa isi media merupakan realitas yang telah dikonstruksikan. Maka dari itu banyak isi dari media tidak menggambarkan kenyataan, karena apa yang ditampilkan telah dikonstruksi sesuai dengan kepentingan tertentu.

Berkaitan dengan strukturasi seperti yang telah dijelaskan sebelumnya bahwa media juga berperan sebagi agen yang memiliki kuasa atas keluwesannya. Strukturasi menggambarkan mengenai perubahan sosial sebagai proses yang mendiskripsikan bagaimana sebuah struktur diproduksi dan direproduksi oleh manusia yang berperan sebagai pelaku dalam struktur itu sendiri.

Sinetron atau sinema elektronik adalah istilah untuk serial drama bersambung yang disiarkan oleh televisi. Sinetron pada umumnya bercerita tentang kehidupan masyarakat yang dibumbui konflik berkepanjangan. Sinetron sudah menjadi bagian dari wacana publik dalam ruang sosial masyarakat. Sinetron tidak hanya menjadi sajian menarik masyarakat tetapi sudah menjadi bahan diskusi, bahkan tidak jarang nilai-nilai sosial didalamnya hadir sebagai rujuan perilaku penggemarnya.

Pada kasus di sinetron Indonesia, kedudukan perempuan masih saja dalam posisi gender kedua. Tema-tema dalam sinteron di Indonesia tidak jauh dari perempuan lemah atau perempuan tertindas, perempuan jahat, atau perempuan yang tidak pintar (bisa dikelabui). Hal ini jelas terlihat pada Sinema Indonsiar yang menampilkan berbagai sifat dan karakter perempuan lemah dan tertindas. Pada judul Sinema Indosiar yang berjudul "Istri yang Tak Dianggap Karena Tak Mampu Memberi Anak Lelaki” menceritakan seorang istri yang telah ketiga kalinya melahirkan anak perempuan, ia justru dianggap sebagai istri yang tak berguna. Karena menurut keluarga sang suami, memiliki keturunan laki-laki merupakan kebanggaan keluarga. Karena tekanan dari orang tua yang begitu besar, sang suami pun memilih jalan pintas dengan mencampakkan istrinya dan menikah dengan wanita lain. Melalui penggambaran kisah ini, TV seolah melanggengkan penindasan terhadap perempuan, perempuan dihadapkan dengan perempuan lainnya sebagai pesaing. Melahirkan yang sesungguhnya adalah anugerah justru menjadi hal yang tidak diinginkan. Hal ini seolah menampilkan fungsi perempuan hanya untuk reproduksi. Sehinga perempuan tidak memiliki hak atas dirinya sendiri. Maka, ini akan menjadikan perempuan kembali pada ranah domestiknya yaitu domestifikasi 


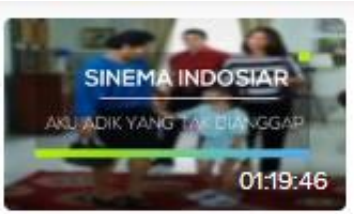

Sinema Indosiar - Aku Adik yang Tak Dianggap INDOSIAR Q

$4.7 \mathrm{~K}$ diputar

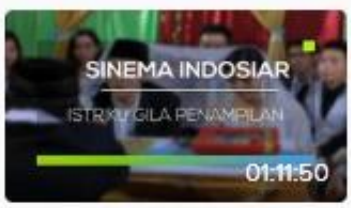

Sinema Indosiar - Istriku Gila Penampilan INDOSIAR ๑

16.0K diputar

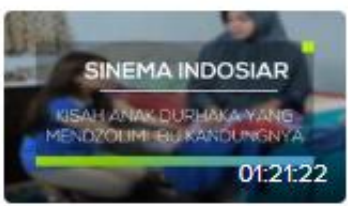

Sinema Indosiar - Kisah Anak Durhaka Yang Mendzolimi lbu Kandungnya INDOSIAR Q

3.3K diputar

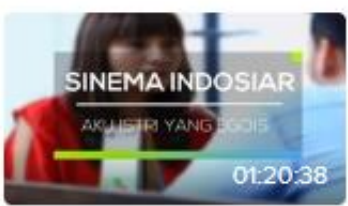

Sinema Indosiar - Aku Istri Yang Egois

INDOSIAR 0

$5.8 \mathrm{~K}$ diputar

Gambar 1: Judul Cerita Televisi di Sinema Indosiar

Sumber: https://www.vidio.com/@indosiar/channels/569403-sinema-indosiar

\section{Domestifikasi Perempuan}

Hingga saat ini masyarakat Indonesia masih dicekik oleh patriarki, kontruksi sosial yang menempatkan laki-laki lebih unggul atau superior terhadap perempuan yang berujung pada kekuasaan laki-laki terhadap tubuh dan peran perempuan. Dalam patriarkal laki-laki punya kekuasaan tertinggi terhadap istri dan anak-anaknya. Pemilikan perempuan mempunyai dua tujuan yaitu melahirkan anak sebagai pewaris laki-laki dan melakukuan kerja reproduksi tenaga kerja seperti melahirkan, mengasuh, dan memasak. Dari sinilah muncul pembagian kerja mutlak sebagai kewajiban suci kaum perempuan. Inilah yang disebut domestifikasi perempuan. Karena tugas-tugas domestik itu dianggap sebagai kewajibab yang terkadang dilegimitasi dengan anggapan budaya atau agama sehingga kerja domestik perempuan berupa pengabdian atau kerja yang tidak dibayar.

Perempuan yang tersubordinat akan mengalami dosmetifikasi. Domestifikasi merupakan proses pengembalian perempuan dalam ranah domestik yaitu melakukan pekerjaan rumah. Bagi Munti (2005), domestifikasi perempuan erat kaitannya dengan mitos tentang perempuaan yakni 3M: masak (memasak), manak (melahirkan), dan macak (merias diri). Posisi perempuan dalam ranah domestik, justru berawal dari keluarga. Perempuan diberikan pekerjaan untuk mengurus rumah tangga, sementara laki-laki bekerja di luar rumah. 
Pandangan subordinat ini kemudian dijelaskan oleh Nunuk Murniati (2004), subordinasi perempuan, dimulai dari perbedaan biologis. Perempuan dilihat secara fisiologis melalui fungsi reproduksinya, lebih dekat kepada alam. Mereka membutuhkan air, tanah, pangan, serta obat-obatan, karena mereka mempunyai kebutuhan untuk menjaga jika haid, hamil, melahirkan, atau menyusui. Kedekatan dengan alam ini membuat perempuan diberi simbol air, tanah, atau yang bersifat "nature". Disisi lain, laki-laki dikaitkan dengan hidup di luar. Fungsinya berburu atau menangkap ikan. Mereka menciptakan sarana dan teknologi untuk melaksanakan fungsinya, sehingga laki-laki diberi label budaya atau nurture. Budaya dianggap membutuhkan daya kreatif yang tinggi dan hasilnya mengalahkan alam, maka muncullah pandangan bahwa nurture menguasai nature. Nurture menghasilkan karya dengan fungsi produksi, sedangkan nature menjalankan fungsi reproduksi.

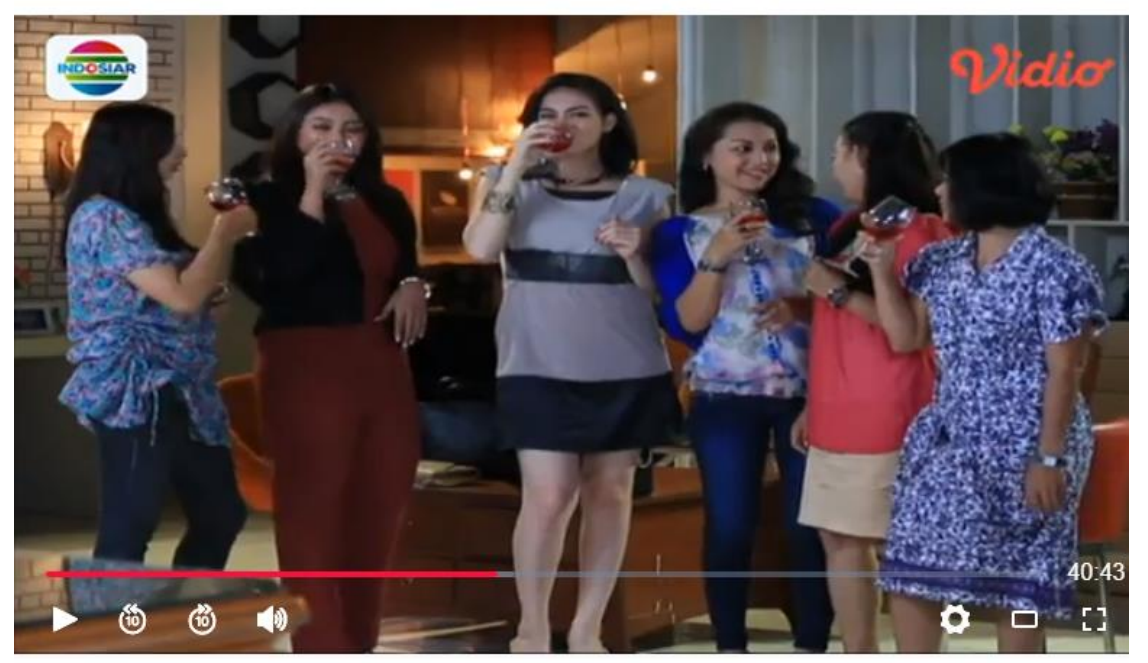

Gambar 2: Potongan Adegan dalam Sinema Indosiar

Sumber: https://www.vidio.com/watch/524848-sinema-indosiar-susahnya-punya-istri-

\section{boros?channel id $=569403$}

Ketika Perempuan melakukan kegiatan di ranah publik, maka perempuan juga harus melakukan pekerjaan rumah, sehingga perempuan menanggung beban ganda (double burdon). Pekerjaan yang dilakukan perempuan dibuat terstruktur oleh budaya patriarki. Fakih (1996) juga mendukung asumsi tersebut, bahwa ketidakadilan gender terjadi di lingkungan rumah tangga. Proses pembagian kerja pengambilan keputusan, dan interaksi antaranggota keluarga dalam rumah tangga dilaksanakan menggunakan asumsi bias gender.

\section{Penutup}

Berangkat dari pemikiran Giddens mengenai strukturasi yang berfokus pada agen dan struktur, tulisan ini mencoba menelaah permasalahan ketidakadilan gender dalam perspektif strukturasi. Melihat kasus ketidakadilan ini telah mengakar pada kehidupan, terutama pada pembagian kerja perempuan yang cenderung mengembalikan perempuan pada ranah domestik. Persoalan ini tentu tidak terlepas pada pengaruh media selaku agen yang memiliki 
kuasa terhadap pembentukan pemikiran khalayak, dan juga peran masyarakat yang memiliki kuasa dalam membentuk struktur sosial. Media memliki power dalam memproduksi dan mereproduksi sebuah wacana. Pada akhirnya, perempuan akan kembali pada ranah domestik, bahkan perempuan justru menanggung beban ganda (double burdon) apabila ia bekerja pada ranah publik, ia juga tetap berkerja di wilayah domestik.

Dalam sinetron Indonesia ketidakadilan gender muncul melalui pembagian watak, pekerjaan ataupun pola pikir aktor yang memerankannya. Seolah menjadi kodrat jika perempuan harus memerankan tokoh yang lembut atau ibu rumah tangga dan laki-laki memerankan tokoh tegas atau pekerja kantor. Kekuatan media televisi pada sinetron Indonesia mampu membangun konstruk dimasyarakat mengenai pembagian gender dalam ranah publik, bahkan mengatur jadwal masyarakat.

\section{REFERENSI}

Barker, Chris. (2005). Cultural Studies: Teori dan Praktik. Penerjemah Nurhadi. Yogyakarta:Kreasi Wacana

Evans, Sara M. (1994). Lahir untuk kebebasan : Sejarah Perempuan Amerika, diterjemahkan oleh Sri Kursdyantinah. Jakarta: Yayasan Obor Indonesia

Fakih, Mansour. (1996). Analisis Gender dan Transformasi sosial. Yogyakarta: Pustaka Pelajar

Giddens, Anthony. (1984). The Constitution of Society: Outline of The Theory of Strucuration. Barkeley: University of California Press

Hollows, Joanne. (2010). Feminisme, Femininity, dan Budaya Populer. Yogyakarta: Jalasutra

Mosco, Vincent. (2009). The Political Economy of Communication. London: Sage Publication

Munti, Ratna Batara. (2005). Demokrasi Keintiman: Seksualitas Di Ero Global. Yogyakarta: Lkis

Murniati, A. Nunuk P. (2004). Getar Gender. Magelang: Indonesia Tera

Puspitasari, Fanny. (2013). Representasi Stereotipe Perempuan dalam Film Brave. Surabaya: Universitas Kristen Petra Surabaya

Ritzer, George dan Douglas J. Goodman. (2010). Teori Sosiologi Modern. Jakarta: Kencana Sunarto. (2009). Televisi, Kekerasan, dan Perempuan. Jakarta: Penerbit Buku Kompas

Tong, Rosemarie Putnam. (1998). Feminist Thought. Yogyakarta: Jalasutra

Trisnawati \& Chelsy Yesicha, Representasi Budaya Matrilineal Minangkabau Dalam Film Tenggelamnya Kapal Van Der Wijck, Jurnal Riset KOmunikasi (Jurkom) Volume 1 Nomor 2Agustus 2018: 276-284 
Listiani, Endri.2015. Bias Gender dalam Sinetron TV. Jurnal : Fakultas Ilmu Komunikasi Universitas Islam Bandung, http://fikom.mercubuana.ac.id/wpcontent/uploads/2015/07/BiasGender_EndriListiani.pdf 